\title{
Efficacy of wilting degree on physiochemical traits and sugar processing parameters of sugar beet roots postharvest
}

\author{
Ferweez, H.*; S. I. El-Syiad** and E.G. I. Mohamed*** \\ *Food Sci. and Techno. Dept, Fac. of Agric., New Valley Branch, Assiut University, Egypt. \\ **Food Sci. and Techno. Dept, Fac. of Agric., Assiut University, Egypt. \\ ***Delta Sugar Factories, Kafr El-Sheikh Governorate, Egypt. \\ Corresponding author: ferweez10@aun.edu.eg
}

\begin{abstract}
Under Egypt conditions sugar beet roots is processed in the factories during the period from the first week of February to Mid of June every year. Whenever, wilting of beet roots carried out at high temperature and low humidity for any cause, which are prevailing during the period from the end of April to Mid of June. So, this work was carried out at laboratories of Delta Sugar Company, Kafr El-Sheikh Governorate, Egypt, as well as Food Science and Technology Department, Faculty of Agriculture, New Valley Branch, Assuit University during 2016 and 2017 working seasons for eight days and replicated four times during the period from $25^{\text {th }}$ April to $6^{\text {th }}$ June.to identify the influencing of wilting degree (the loss \% in moisture content of beet roots) postharvest on physiochemical traits, impurities contents and processing efficiency parameters of sugar beet roots.

The obtained results revealed that wilting degree of beet root had a significant effect on physical properties of sugar beet juice expressed as total soluble solids \%(TSS\%), $\mathrm{pH}$ value, bulk density $(\mathrm{kg} / \mathrm{m} 3)$ and color of raw juice (Icumsa units); impurities contents of sugar beet,i.e. $\mathrm{a}-\mathrm{N}, \mathrm{K}$ and $\mathrm{Na}$ (millieq./100g), and chemical composition of sugar beet roots ,i.e. pol \%, reducing sugars $\%$ and dextran content as well as processing efficiency parameters of sugar beet roots, i.e. juice purity $\%$, sucrose recovery $\%$, sugar losses $\%$ in waste, quality index of beet roots and weight losses $\%$ of beet roots.

We hope that the above-mentioned results in this work would help understand the changes which take place in sugar beet roots postharvest caused by the wilting, which cause significant economic losses in sugar production and to know the practices that reduce sugar loss during processing. Here, we demonstrate that all sugar beet growers and the processors' benefit directly when postharvest losses are minimized. The increase in wilting degree of beet roots means make them lose their refreshment and affect negatively sugar extraction during manufacturing in sugar factories.
\end{abstract}

Keywords: Sugar beet, pol \%, wilting, SR\%, Quality index , TSS\% and a-N

\section{Introduction}

Sugar beet plays a prominent role in sugar production in Egypt. There is an intention in the policy of the Egyptian government to expand the cultivation of sugar beet, consequently, the number of beet factories is increasing. The importance of sugar beet to agriculture is not only confined to sugar production but also for its secondary products (Badawy,1992). Beet cultivars were imported mostly from Europe. Sugar beet is facing some problems with respect to climate and variety of sugar beet related to postharvest like weight losses, rotting and staleness leading to declined sugar recovery. It is desirable that beet roots should have a high pol\%, on its own, but pol\% of beet roots is an incomplete quality criterion. In addition, beet sugar production reached $57 \%$ of the local sugar production (2.3 million tons ) in 2016 (CCSC, 2017) .

A harvested beet roots continues to live by respiration and consumption of its sugar which is considered sugar loss (Asadi, 2007). Its respiration is important to maintain life. It is subject also to microbiological attack. Sugar loss begins on the first day postharvest and rapidly increases. Wilt of root meaning, relating to moisture loss under various conditions of temperature and relative humidity and the respiration and sugar losses associated with such dehydration. Beet roots become weak, shrinkage and begin to bend towards the ground and also affects their appearance, texture and quality. Therefore the water loss as a result of roots wilting will result in weight losses. The weight loss of roots vary in different conditions of temperature, relative humidity as well as size and shape of beet roots or exhibition surface.

Abbas and Fugate (2009) pointed out that Sugar beet (Beta vulgaris L.) roots lose water during storage and often become severely dehydrated after prolonged storage and at the outer regions of storage piles which have greater wind and sun exposure. Sucrose loss is known to be elevated in dehydrated roots, although the metabolic processes responsible for this loss are unknown. Wilting degree (the loss moisture content of beet root postharvest) which take place as a result of the delaying in transporting and processing of beets and such as when a problem at any stage of processing is occurred resulted a rapid qualitative deterioration and high quantitative losses (Davis ,1982). Postharvest, sugar beet roots outdoors at temperature above $7^{\circ} \mathrm{C}$, rotting can become an appreciable factor, and the final result can be complete loss as reported by Ishikuri, et al.,(1992). Prolonged period of sugar beets postharvest and before processing requires to be healthy and clean to minimize sugar losses due to 
extraneous conditions related to internal damage, still, a considerable part of such losses could be due to intercellular conversion of sucrose to glucose and fructose. The enzyme responsible for sucrose splitting is invertase, Sakalo and Tyltu (1997).

There is little information on the impact of wilting degree on physiochemical traits and impurities contents of beet roots. Dehydration or wilting of beet roots begins immediately postharvest and generally increases with the delaying duration than manufacturing of sugar beet in sugar factories. The increase in wilting degree of beet roots means the reduction in water content of beet roots make them lose their refreshment and affect negatively sugar extraction at manufacturing in sugar factories. So, the objective of the present investigation was carried out to identify the influencing of wilting degree (the loss moisture content of beet root) postharvest on physiochemical traits, impurities contents and processing efficiency parameters of sugar beet roots.

\section{Materials and Methods}

The trail was carried out at laboratories of Delta Sugar Company, Kafr El-Sheikh Governorate, Egypt, as well as Food Science and Technology Department, Faculty of Agriculture, New Valley Branch, Assuit University at 2016 and 2017 working seasons for eight days and replicated four times during the period from $25^{\text {th }}$ April to $6^{\text {th }}$ June. The samples of sugar beet roots (Beta vulgaris L.) of different working cultivars (Top, Pleno, Farida, Raspoly, Tribel, Maribo, marcopoly and kawimera) were taken from the research fields of Delta Sugar Company to identify the influencing of wilting degree (the loss moisture content of beet root for any cause ) postharvest on physiochemical properties, impurities contents and processing efficiency parameters of sugar beet roots. The experimental design was a randomized complete block with four replicates and six treatments. The research site was selected because it was usually represented the largest Factory of beet sugar production in Egypt. Samples of beet roots (about $30 \mathrm{~kg}$ beet roots) were taken at random from the studied different wilting degrees as follow:

1- $0 \%$ or No wilt (at harvest or control).

2- $4.88 \%$ or Slight wilting (at 2 days postharvest) .

3- $8.61 \%$ or Moderate wilting (at 4 days postharvest).

4- $14.14 \%$ or High wilting (at 6 days postharvest).

5- $18.41 \%$ or very high wilting (at 8 days postharvest).

On the harvest day (after 195 days from sowing date), a sample of approximately half ton was obtained from the healthy vegetative homogenous beet roots of sugar beet in four replicated times. The sample of each treatment was topped, cleaned and thoroughly mixed into a pile. Beet roots piles were left under open field conditions in order to study the changes in quality and weight. Aerobic atmosphere conditions were temperature from $27.5-33.5^{\circ} \mathrm{C}$ and relative humidity from $77-85 \%$.

Wilting degree of beet root was calculated as follow :

Wilting degree of beet root $=$ The moisture $\%$ of beet root at harvest - The moisture\% of beet root at the studied period $X 100 /$ The moisture $\%$ of beet root at harvest

Determination of physiochemical traits and processing efficiency parameters at the studied wilting ratios:

Samples of beet roots (about 0.5 ton of beet roots) of the above-mentioned different working cultivars were taken at random and divided separately into five categories, each containing about $100 \mathrm{~kg}$ of roots. Four categories of roots were used for determination of the changes in the weight and the other category was used for determination of the changes in the chemical composition of beet roots. Samples of roots at the different wilting ratios, i.e. $0,4.88,8.61,14.14$ and $18.41 \%$ were send to the laboratory for analysis. Samples of beet roots were cleaned with running tap water, dried. Each sample was grated separately with grater into cossettes and mixed thoroughly to determine the physiochemical traits of beet roots as follow:

\section{I-Physical traits of beet roots :}

Total soluble solids\% (T.S.S\%): Total soluble solids of fresh samples were determined using fully automatic digital refractometer; model ATR-S (04320), 0 - 95\% Brix, temperature compensation 15 to $40{ }^{\circ} \mathrm{C}$ according to procedure of Delta sugar Company. pH measuring: $\mathrm{pH}$ value of beet samples measuring by using digital bench $\mathrm{pH}$-meter, model $\mathrm{pH}$ 526/sentix-20/AS- DIN / SIN / STH / 650 according to procedure of Delta sugar Company.

Bulk density of beet samples was determined by $\mathbf{k g} / \mathbf{m}^{\mathbf{3}}$ according to procedure of Delta sugar Company as described in A.O.A.C. (2005).

Color of raw juice of beet samples was measuring by spectrophotometer at $420 \mathrm{~nm}$ as Icumsa units according to procedure of Delta sugar Company as described in A.O.A.C. (2005).

\section{II-Chemical composition of beet roots:}

Moisture content:The moisture content was determined by drying samples to constant weight at in aluminum weighing dishes at $105^{\circ} \mathrm{C}$ for $24 \mathrm{~h}$. , using the air oven-drying method according to A.O.A.C. (2005).

Sucrose content: Sucrose content was determined using automatic saccharimeter on a lead acetate basis according to procedure of Delta Sugar Company, Le Docte (1977). 
Reducing sugar: Reducing sugar content of beet roots samples were determined using Ofner's volumetric methods as described in A.O.A.C. (2005)

Dextran content (ppm): Dextran in fresh and stored samples was determined according to procedure of Roberts (1983).

III-Impurities contents of beet roots :

Alpha amino nitrogen, Sodium and potassium contents/ 100 g beet:

Alpha amino nitrogen, sodium and potassium were determined using venma, Automation BV Analyzer IIG-16-12-99, 9716JP/ Groningen / Holland. Temp. 18 $-30^{\circ} \mathrm{C}$, surrounding humidity max. $70 \%$ according to Brown and Lillan (1964), the results calculated as milli equivalents / $100 \mathrm{~g}$ beet.

\section{IV-The processing efficiency parameters of sugar} beet :

Purity $=($ sucrose $\% .100) /($ T.S.S \% $)$

Quality index $=($ SR.100 $) /$ pol.

$\mathrm{SR}=($ pol-0.29) $-0.343(\mathrm{k}+\mathrm{Na})-\alpha \mathrm{N}(0.0939)$

Where:

Pol $\%=$ Sucrose $\%, \mathrm{~K}=$ Potassium, $\mathrm{Na}=$ Sodium, $\alpha-\mathrm{N}=$ Alpha-amino nitrogen,

$\mathrm{SR} \%=$ Sugar recovery $\%$ and $\mathrm{TSS} \%=$ total soluble solids\%

Sugar losses in wastes (SL): Sugar losses in wastes percentage were determined according to the procedure of Delta Sugar Company using the following equation: group by using electrical balance LHW $-120 \times 0.02$ $\mathrm{kg}$, model HW according to procedure of Delta sugar Company

The presented results in the work are average of 2016 and 2017 seasons.

Statistical analysis:

Collected data were subjected to the proper analysis of variance (ANOVA). The proper statistical of all data was carried out according to lined by Gomez \& Gomez (1984). Homogeneity of variance and differences among treatments were evaluated by the least significant difference test (LSD) at 5\%. The results were as averages of four times during the period from $25^{\text {th }}$ April to $6^{\text {th }}$ June.

\section{Results and Discussion}

\section{I- Normal physiochemical parameters of beet roots during working season:}

Sugar beet roots composition (the raw material of the beet sugar factory) is important to both the sugar beet farmer and the factory. Determination of sugar (sucrose) and non-sugar (non-sucrose) contents in beet roots define quality of beet roots, where, high sugar and low non-sugar contents are desirable. So it is important to evaluate the physiochemical properties of beet roots in order to evaluate the quality of different fresh sugar beet roots for sugar production. The results recorded in Table 1. summarized normal $\mathrm{SL}=0.343(\mathrm{~K}+\mathrm{Na})+\alpha . \mathrm{N}(0.094)+0.2$ hysiochemical parameters averages of sugar beet roots during working season of beet roots processing without wilting degree of beet roots postharvest. The present results are in agreement with the findings of by Gomaa (2009) . escribed by Silin and Silina (1977) and Sapronova et al. (1979).

Mass or weight losses in beet roots :The mass loss was determined of the specific samples for each

Table 1. Physiochemical properties average of different fresh sugar beet roots during processing working season in(average of 2016 and 2017seasons) for the studied different cultivars.

\begin{tabular}{lc}
\hline Parameters & working season(2017) \\
\hline Moisture content \% & 77.82 \\
\hline Total soluble solids (T.S.S) \% & 21.23 \\
\hline Sucrose (pol) \% & 18.23 \\
\hline Reducing sugar\% & 0.13 \\
\hline$\alpha-N$ nitrogen (milliequ./100g beet) & 1.81 \\
\hline Sodium (milliequ./100g beet) & 1.93 \\
\hline Potassium (milliequ./100g beet) & 6.07 \\
\hline Dextran content (ppm) & 79.33 \\
\hline
\end{tabular}

* Each value was an average of ten determinations

\section{II-Effect of wilting degree on physical properties of beet roots:}

Data in Table (1) clarified that wilting degree of beet root caused by leave of sugar beet roots for $0-8$ days in open air during the beet campaign (beetprocessing period) had a significant effect on physical properties of sugar beet juice expressed as total soluble solids \%(TSS\%), pH value, Bulk density $(\mathrm{kg} / \mathrm{m} 3)$ and Color of raw juice (Icumsa units). The increase in wilting degree of beet roots from 0.00 or no wilt to slight wilting, moderate wilting, high wilting and very high wilting led to increasing in the TSS \% of beet root by $10.08,18.22,32.09$ and $36.99 \%$, Bulk density $\left(\mathrm{kg} / \mathrm{m}^{3}\right)$ of beet roots increased by $1.49,2.24,4.26$ and $10.38 \%$ and color of extracted raw juice (Icumsa units) increased by $17.29,25.99,29.64$ and 32.07 of the control value, respectively. This result is might be attributed to the gradually decrease in moisture content of beet roots with increasing wilting degree of beet roots as the processing days delayed from zero time (at harvest) up to 8 days. The obtained results are in general acceptance with those recorded by Al.Jbawi 
\& Al.Zubi (2016) and El.Hefnawy (2016). They reported that sugar beet roots are considerable perishable materials to wilting because of its high moisture content $(75.00 \%)$

Table2. Effect of wilting degree on physical properties averages of fresh beet roots stored for 0-8 days in open air.

\begin{tabular}{lcccc}
\hline \multicolumn{1}{c}{ Wilting degree } & TSS\%* & pH value & $\begin{array}{l}\text { Bulk density } \\
(\mathrm{kg} / \mathrm{m3})\end{array}$ & $\begin{array}{l}\text { Color of raw juice } \\
\text { (Icumsa units) }\end{array}$ \\
\hline No wilt (at harvest ) & 21.63 & 6.60 & 671.30 & 20525.33 \\
\hline Slight wilting & 23.81 & 6.73 & 681.33 & 24074.67 \\
\hline Moderate wilting & 25.57 & 6.49 & 687.33 & 25860.00 \\
\hline High wilting & 28.57 & 6.38 & 692.00 & 266080.00 \\
\hline Very high wilting & 29.63 & 6.31 & 697.00 & 27106.67 \\
\hline Overall mean & 25.83 & 6.50 & 697.00 & 24834.93 \\
\hline F value & $* *$ & $* *$ & $* *$ & $*$ \\
\hline LSD 0.05 & 0.93 & 0.07 & 5.54 & 1660.30
\end{tabular}

TSS\%*= Total soluble solids \%

III-Effect of wilting degree on chemical composition of beet roots:

From the data tabulated in Table (3) pointed out that wilting degree of beet root had a significant effect on components averages of chemical composition of sugar beet roots, i.e. pol \%, reducing sugars $\%$ and dextran content . There were a gradual decrease in pol $\%$ (on DWB) by $12.86,19.90,26.50$ and $35 \%$ of the control value with increasing wilting degree of beet roots from 0.00 or no wilt to slight wilting, moderate wilting, high wilting and very high wilting, respectively. However, this an increase in wilting degree of beet roots led to increasing in the dextran content of beet root by $22.27,36.14,52.94$ and $93.28 \%$ of the control value, respectively. Wilting degree of beet roots postharvest is associated with a loss of sucrose or pol \% and overall root quality. This decrease in pol\%(on DWB) of beet roots with increasing wilting degree of beet roots is might be attributed to respiration process, where, represent 70 $80 \%$ of the sucrose or pol losses that take place postharvest. While, the increase in dextran content of beet roots postharvest is might be attributed to the microbiology activity. The increase in wilting degree of beet roots means the reduction in water content of beet roots make them lose their refreshment and affect negatively sugar extraction during manufacturing in sugar factories. These results are in correspondence with the findings of Abou EL-Magd and Nariman (2004); Asadi (2007) ; Gomaa (2009); Al.Jbawi \& Al.Zubi (2016) and El.Hefnawy (2016). They revealed that sugar loss of sugar beet postharvest represents a substantial decrease in revenue for sugar industry and can have a significant economic impact.

In the light of the results obtained from this study that there was the adversely relationship between wilting degree of beet roots and processing efficiency parameters of sugar beet roots.

Table3. Effect of wilting degree on chemical composition averages of fresh beet roots stored for 0-8 days in open air.

\begin{tabular}{lcccc}
\hline \multicolumn{1}{c}{ Wilting degree } & Moisture \% & Pol \%* & $\begin{array}{l}\text { Reducing sugars } \\
\%\end{array}$ & $\begin{array}{l}\text { Dextran } \\
(\mathbf{p p m})\end{array}$ \\
\hline No wilt (at harvest) & $\mathbf{7 7 . 8 2}$ & $\mathbf{8 2 . 3 5}$ & $\mathbf{0 . 1 3}$ & $\mathbf{7 9 . 3 3}$ \\
\hline Slight wilting & $\mathbf{7 4 . 0 2}$ & $\mathbf{7 2 . 9 7}$ & $\mathbf{0 . 2 4}$ & $\mathbf{9 7 . 0 0}$ \\
\hline Moderate wilting & $\mathbf{7 1 . 1 2}$ & $\mathbf{6 8 . 6 8}$ & $\mathbf{0 . 0 8}$ & $\mathbf{1 0 8 . 0 0}$ \\
\hline High wilting & $\mathbf{6 6 . 8 2}$ & $\mathbf{6 5 . 1 0}$ & $\mathbf{0 . 0 6}$ & $\mathbf{1 2 1 . 3 3}$ \\
\hline Very high wilting & $\mathbf{6 3 . 4 9}$ & $\mathbf{6 1 . 0 0}$ & $\mathbf{0 . 0 5}$ & $\mathbf{1 5 3 . 3 3}$ \\
\hline Overall mean & $\mathbf{7 0 . 6 5}$ & $\mathbf{7 0 . 0 2}$ & $\mathbf{0 . 1 1}$ & $\mathbf{1 1 1 . 8 0}$ \\
\hline F value & $* *$ & $* *$ & $* *$ & $*$ \\
\hline LSD 0.05 & $\mathbf{0 . 7 1}$ & 5.54 & & 16.48 \\
\hline
\end{tabular}

Pol \%* calculated as dry weight basis (DWB)

\section{IV-Effect of wilting degree on impurities contents} of beet roots:

The results of impurities contents of beet root, i.e. alpha amino nitrogen (a-N), potassium (K) and sodium $(\mathrm{Na})$ contents are presented in Table (4) .It could be noted that wilting degree exhibited a significant effect on impurities contents of sugar beet roots. There were a gradual increase in a-N content of beet roots by $38.12,49.17,56.35$ and $62.43 \%$; $\mathrm{K}$ content of beet roots increased by $1.32,4.28,6.26$ and $7.43 \%$, and $\mathrm{Na}$ content of beet roots increased by $16.06,23.32,31.09$ and $40.93 \%$ of the control value 
with increasing wilting degree of beet roots from no wilt to slight wilting, moderate wilting, high wilting and very high wilting, respectively. This increase is might be attributed to the gradually increase in dry matter content of beet roots with increasing wilting degree of beet roots as the processing days delayed from zero wilt (at harvest) up to 8 days. Technical knowledge of the impurities contents of beet roots is important in processing of sugar beet roots because it had a highly deteriorate effect on juice purification and sugar crystallization (Draycott,2006). These results are in the same line with those of Asadi (2007). He indicated that there was a negative relationship between the impurities content of beet roots and recoverable sugar yield produced from sugar beet .

Table4. Effect of wilting $\%$ on impurities contents of fresh beet roots stored for 0-8 days in open air.

\begin{tabular}{lccc}
\hline \multicolumn{1}{c}{ Wilting degree } & a amino nitrogen content $*$ & Potassium content* & Sodium content* \\
\hline No wilt $\quad$ (at harvest) & 1.81 & 6.07 & 1.93 \\
\hline Slight wilting & 2.50 & 6.15 & 2.24 \\
\hline Moderate wilting & 2.70 & 6.33 & 2.38 \\
\hline High wilting & 2.83 & 6.45 & 2.53 \\
\hline Very high wilting & 2.94 & 6.54 & 2.72 \\
\hline Overall mean & 2.55 & 6.31 & 2.36 \\
\hline F value & $* *$ & $* *$ & $* *$ \\
\hline LSD 0.05 & 0.46 & 0.36 & 0.21
\end{tabular}

\section{*Determined as milliequavalent / $100 \mathrm{~g}$ beet}

\section{V-Effect of wilting degree on processing efficiency} parameters averages of beet roots:

Weight loss of beet roots, expressed as a percentage of the root's weight at the beginning of the experiment. It could be scored from results in Table (5) that wilting degree exhibited a significant effect on processing efficiency parameters of sugar beet roots, i.e. juice purity $\%$, sucrose recovery $\%$, sugar losses $\%$ in waste, quality index of beet roots and weight losses $\%$ of beet roots. There were a gradual decrease in juice purity $\%$ of beet roots by $7.99,11.99,13.59$ and 14.21 $\%$; sucrose recovery $\%$ of beet roots decreased by 4.91 , $11.35,20.54$ and $36.29 \%$ and quality index of beet roots decreased by $4.15,5.29,11.17$ and $17.96 \%$ of the control value, while, sugar losses $\%$ in beet roots increased by $12.56,16.87,20.05$ and $25.28 \%$ of the control value with increasing wilting degree of beet roots from no wilt to slight wilting, moderate wilting, high wilting and very high wilting, respectively. This decrease in juice purity $\%$, sucrose recovery $\%$ and quality index of beet roots is might be attributed to the gradually decrease in pol \% or sucrose content of beet roots on dry weight basis depend entirely on respiration to supply the energy with increasing wilting degree. While, the gradually increase in sugar losses \% of waste and weight losses \% of beet roots is might be attributed to the gradually decrease in pol \% or sucrose content of beet roots with increasing wilting degree of beet roots. Weight loss of beet roots was mainly due to a decrease in root water content. These data are in agree with those obtained by Ferweez $\boldsymbol{e t}$ al.,(2006); Abbas and Fugate (2009); Dewdar et al., (2015); Al.Jbawi \& Al.Zubi (2016) and El.Hefnawy (2016). They exhibited that this decrease might be due to some natural vital functions such as respiration and sprout formation. Here too, they reported that respiration rate declined in response to low levels of water loss and respiration is the primary cause of postharvest sucrose loss in sugar beet roots.

Table5. Effect of wilting degree on processing efficiency parameters averages of fresh beet roots stored for 0-8 days in open air.

\begin{tabular}{lccccc}
\hline \multicolumn{1}{c}{ Wilting degree } & $\begin{array}{c}\text { Juice purity } \\
\%\end{array}$ & $\begin{array}{c}\text { Sucrose } \\
\text { recovery } \%\end{array}$ & $\begin{array}{l}\text { Sugar losses\% } \\
\text { in waste }\end{array}$ & $\begin{array}{l}\text { Beet quality } \\
\text { index }\end{array}$ & $\begin{array}{l}\text { Weight losses\% } \\
\text { in beet roots }\end{array}$ \\
\hline No wilt (at harvest) & $\mathbf{8 5 . 8 2}$ & $\mathbf{6 7 . 8 9}$ & $\mathbf{3 . 2 0}$ & $\mathbf{8 2 . 3 8}$ & $\mathbf{0 . 0 0}$ \\
\hline Slight wilting & $\mathbf{7 9 . 4 7}$ & $\mathbf{6 4 . 7 1}$ & $\mathbf{3 . 6 5}$ & $\mathbf{7 9 . 1 0}$ & $\mathbf{1 2 . 5 6}$ \\
\hline Moderate wilting & $\mathbf{7 6 . 6 3}$ & $\mathbf{6 0 . 9 7}$ & 4.03 & $\mathbf{7 8 . 2 4}$ & $\mathbf{1 6 . 8 7}$ \\
\hline High wilting & $\mathbf{7 5 . 5 5}$ & $\mathbf{5 6 . 3 2}$ & 4.37 & $\mathbf{7 4 . 1 0}$ & $\mathbf{2 0 . 0 5}$ \\
\hline Very high wilting & $\mathbf{7 5 . 1 4}$ & 49.81 & $\mathbf{5 . 0 2}$ & $\mathbf{6 9 . 8 4}$ & $\mathbf{2 5 . 2 8}$ \\
\hline Overall mean & $\mathbf{7 8 . 5 2}$ & $\mathbf{5 9 . 9 4}$ & 4.06 & $\mathbf{7 6 . 7 3}$ & 14.95 \\
\hline F value & $* *$ & $* *$ & $* *$ & $* *$ & $* *$ \\
\hline LSD 0.05 & $\mathbf{3 . 9 4}$ & 4.48 & $\mathbf{0 . 1 3}$ & $\mathbf{2 . 2 8}$ & $\mathbf{1 . 6 0}$ \\
\hline
\end{tabular}

* Sucrose recovery\% of pol \% of sugar beet roots on dry weight basis (DWB).

We hope that the above-mentioned results in this work would help sugar beet growers and the processors' to understand the changes which take place in the physiochemical properties and processing efficiency parameters of sugar beet roots postharvest caused by the wilting. It is has the potential to cause 
significant economic losses in sugar production and known the practices that reduce sugar loss during processing. Wilting is common in postharvest sugar beet roots and is known to increase sugar loss postharvest. Unknown, however, is the proportion of wilting-associated sugar loss that is attributable to elevations in respiration rate, since sugar is lost not only to respiration, but also to conversion to other carbohydrates, and to storage rots and diseases. The increase in wilting degree of beet roots means make them lose their refreshment and affect negatively sugar extraction during manufacturing in sugar factories. Here, we demonstrate that wilting is might be associated with an increase in root respiration. All sugar beet growers and the processors' benefit directly when postharvest losses are minimized. It is not advisable to wilting of beet roots postharvest before the processing in order to prevent the dislike changes and damage in pol content and weight of sugar beet roots.

\section{Acknowledgment}

Thanks to the Sugar beet Research Board of Delta Sugar Company, Kafr El-Sheikh Governorate, Egypt for assisting in this work and conducting quality analysis.

\section{References}

A.O.A.C. (2005). "Official Methods of Analysis. Association of Official Analytical Chemists". Washington 18 D.C., USA.

Abbas M. L. and K. K. Fugate (2009). Dehydration accelerates respiration in postharvest sugarbeet roots . Postharvest Biology and Technology 54 (2009) 32-37

Abou El- Magd, B.M. and Nariman O.A. (2004). Effect of some chemical treatments on the chemical quality and storability of sugar beet roots after harvest. Egypt. J. Appl. Sci., 19(11): 263-277.

Al.Jbawi, E.M. and H.I.Al.Zubi(2016): Effect of sowing dates and length of storage on storability in sugar beets (Beta vulgaris L.) pile .Scholarly journal of Agricultural Sci., 6(1):25-31.

Asadi M. (2007). Beet-Sugar Handbook. John Wiley and Sons, Inc.

Hoboken, New Jersey, pp. $99-289$.

Badawy, E.M. (1992). Biochemical studies on sugar metabolism in sugar beet plants. Ph.D. Thesis, Fac. of Agric., Menoufiya Univ.

Brown, J.D and Lilland, O. (1964). Rapid determination of potassium and sodium by flam photometry. Proc. Amer. Soc. Hort. Sci., 48, 341316.

CCSC . (2017). Central Council for Sugar Crops , Ministry of Agriculture , Egypt, Annual Report Book.

Davis, D.C. (1982). Moisture control and storage systems of vegetable crops. In: drying and storage of agriculture crops. The ANI publishing comp. INC. Westport, USA.

Dewdar, M. D. H.; Abbas, M. S.; Gaber, E. I. and Abd El-Aleem, H. A. (2015). Influence of Time Addition and Rates of Boron Foliar Application on Growth, Quality and Yield Traits of Sugar Beet. Int.J.Curr.Microbiol.App.Sci. 4(2): 231-238.

Draycott , A.P.(2006): Sugar beet . Blackwell Pub.UK.

El.Hefnawy, Kh.M.Kh.(2016) : Chemical and technological studies on sugar beet . M.Sc. Thesis, Fac. of Agric. Damietta Univ.

Ferweez, H.; Abbas, H.M. and Abou El-Magd, B.M. (2006). Determination of the losses in yield, quality and profitability of sugar beet roots resulted from exceeding nitrogen fertilization and processing delay. Minia J. of Agric. Res. And Develop., 26(1): 27-44.

Gomaa, S. (2009).Effect of calcium hydroxide and acetic acid on the rat of deterioration and dextran formation during sugar beet storage. M.Sc. Thesis, Sugar Techn. Research Inst., Assiut Univ.

Gomez, K.A. and A.A. Gomez (1984).Statistical procedures for agricultural Research, Second Edition .John Willey and Sons, New York, pp.680.

Ishikuri, S.;Uchino,H.and Kanzawa,K. (1992). Isolation of pseudomonas cepacia D-202: an available biocontrol agent to storage rot of sugar beet. Annuals of the phytopathological society of Japan, 58(3): 456-460.

Le Docte, A. (1977). Commercial determination of sugar in sugar beet using the socks sugar J., 29, 488-492.

Sakalo,V.D.and Tyltue,A.S. (1997). Enzymes of carbohydrate metabolism in sugar beet roots in the course of short term storage under unfavorable conditions. Russian Journal of plant physiology, 44(1): 70-76.

Sapronova, A.; Joshman, A. and loseava, V. (1979). General technology of sugar and sugar substances. Pischevaya promyshennost pub. Moscow.

Silin, P.M. and Silina, N.P. (1977). Chemical control in sugar technology. Food Technol., pub. USSR, pp 120-126. 


\section{تاثير درجة ذبول جذور بنجر بعد الحصاد على الصفات الفيزوكيميائية}

\section{و مؤثرات كفاءة تصنيع السكر}

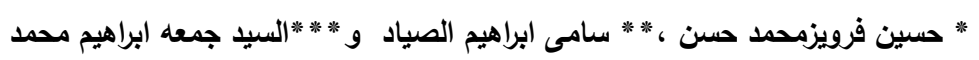

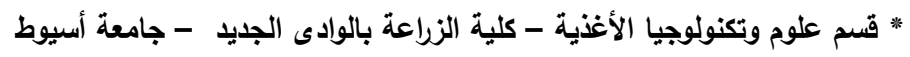

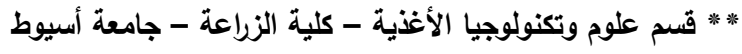

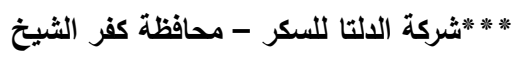

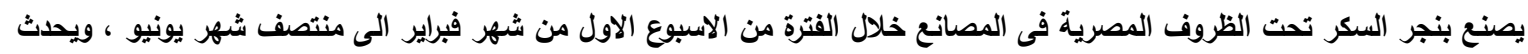

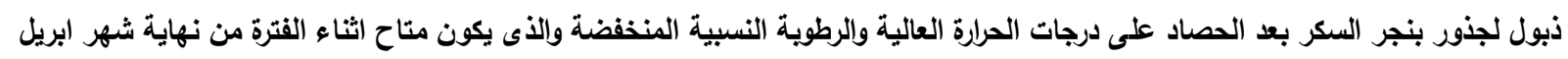

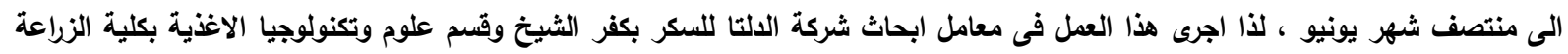

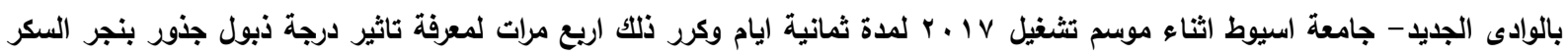

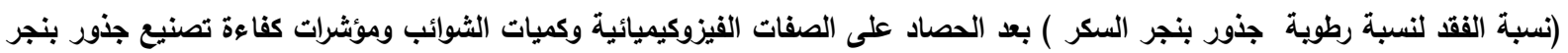

اوضحت النتائج المتحصل عليها الاتى :

1- حقق مستوى درجة ذبول جذور بنجر السكر تاثير معنوى على الصفات الطبيعة للمادة الخام لتصنيع السكر (جذور البنجر ) كنسبة المواد

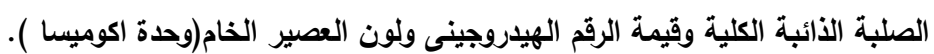

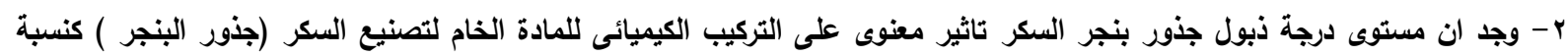

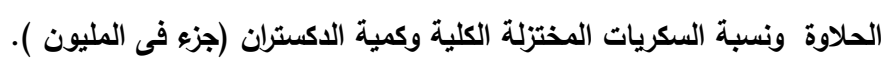

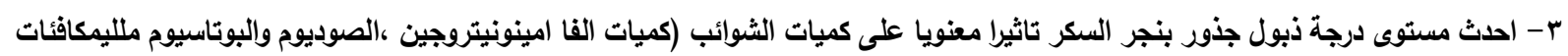

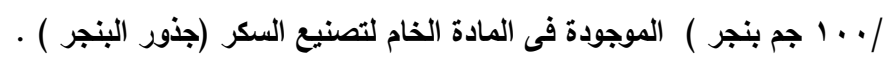

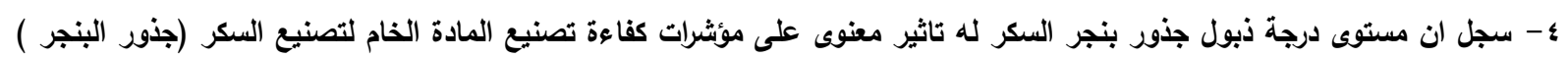

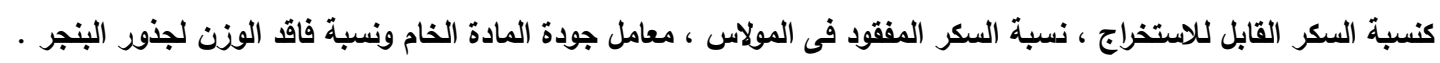

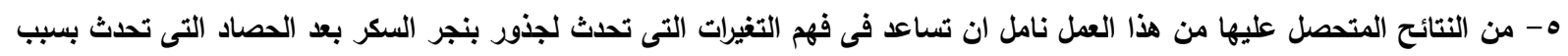

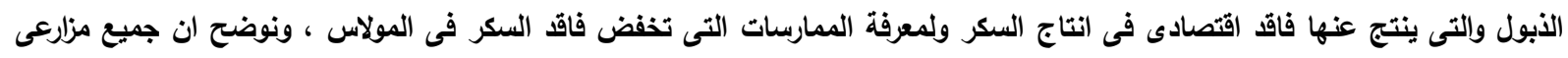

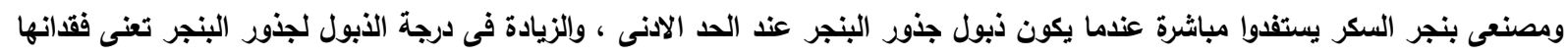

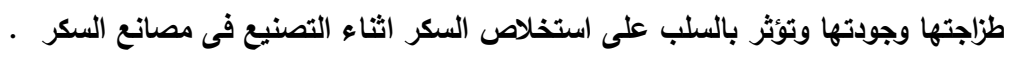


